\title{
ANALISIS PENGARUH KINERJA KEUANGAN, MANAJEMEN RISIKO DAN MANAJEMEN MODAL KERJA TERHADAP RETURN SAHAM
}

(Studi Kasus Pada Perusahaan Telekomunikasi Yang Listing Di BEI Tahun 2010-2013)

\author{
Dwian Wahyu Prabawa ${ }^{1}$ dan Fitri Lukiastuti ${ }^{2}$ \\ STIE Bank BPD Jateng \\ ${ }^{1}$ chrisbonaparte12@gmail.com, ${ }^{2}$ flaluki@yahoo.com
}

\begin{abstract}
Level stock returns telecommunications in Indonesia is influenced by various factors such as financial performance, risk management and working capital management. The purpose of this research was to analyze the influence of financial performance through parameters Debt to Equity Ratio (DER), Return On Investment (ROI), Current Ratio (CR) dan Total Assets Turn Over (TATO). Risk management using parameters (interest rate) and working capital management using parameters Cash Conversion Cycle (CCC). The population in this study is a telecommunications companies listed in Indonesia Stock Exchange 2010-2013. In analyzing the effect of variable DER, ROI, CR, TATO, ir and CCC using multiple linear regression. The analysis showed that the Debt to Equity Ratio (DER) has effect on stock returns with significant value 0,009, Return on Investment (ROI) has effect on stock returns with significant value 0,006. And Total Asset Turn Over (TATO) has effect on stock returns with significant value 0,025 . While the Current Ratio (CR), interest rate, and Cash Conversion Cycle not effect on stock returns with significant value 0,$403 ; 0,047 ; 0,977$. All the independent variables simultaneously affect the stock on telecommunication companies.
\end{abstract}

Keywords: Financial Performance, Risk Management, Working Capital Management, Stock Return, Telecommunications

\section{PENDAHULUAN}

Kondisi perekonomian Indonesia yang menunjukkan kestabilan membuat tingkat kesejahteraan masyarakat menjadi semakin membaik. Hal ini dibuktikan dengan peningkatan pendapatan perkapita yang diikuti dengan tingkat daya beli masyarakat (BPS, 2014). Meningkatnya kesejahteraan masyarakat berpengaruh terhadap pola kehidupan, termasuk dalam hal investasi. Masyarakat telah menyadari pentingnya melakukan investasi untuk masa depan yang lebih baik. 
Terdapat berbagai macam pilihan yang dapat dilakukan oleh investor untuk

JURNAL

MANAJEMEN

INDONESIA

Vol. 15 - No. 1

April 2015 memanfaatkan kelebihan dana yang dimiliki. Investor selalu berusaha untuk mencari investasi yang menjanjikan keuntungan dengan berbagai pilihan risiko yang ada. Menurut Hermi dan Kurniawan (2011) investasi dalam bentuk saham memiliki risiko yang sangat besar. Kesalahan dalam pemilihan saham yang akan dibeli dapat mengakibatkan kerugian yang fatal bagi investor. Oleh sebab itu investor harus mampu memilih dengan baik saham yang akan dibeli.

Pasar modal merupakan pasar yang didefinisikan sebagai tempat untuk berbagai instrument keuangan (sekuritas) jangka panjang yang dapat diperjualbelikan, dalam bentuk hutang maupun modal sendiri, baik yang diterbitkan oleh pemerintah, public authorities, maupun pihak swasta (Husnan, 1994). Listing di Bursa Efek Indonesia (BEI) merupakan salah satu cara bagi emiten untuk memperoleh dana segar dari pasar modal (Thrisye dan Simu, 2013). Investor dapat memilih berbagai instrumen investasi yang ditawarkan sesuai dengan kebutuhan didalam pasar modal. Semakin banyaknya emiten yang menerbitkan surat berharga mendorong minat investor untuk memilih pasar modal sebagai alternatif sarana investasi yang menjanjikan.

Saat melakukan investasi, investor mengharapkan pengembalian investasi (return) dari investasi yang dilakukan, pengembalian (return) ini dapat berupa dividen apabila investor melakukan investasi dengan membeli saham di pasar modal. Sedangkan untuk investasi dengan membeli obligasi investor akan mendapatkan kupon. Tingkat pengembalian (return) yang diberikan perusahaan kepada investor tentunya berbeda antar perusahaan satu dengan yang lainnya. Perbedaan kinerja perusahaan sangat mempengaruhi besarnya tingkat pengembalian (return) yang akan diterima investor.

Return merupakan tingkat pengembalian yang diberikan perusahaan kepada para investor sebagai balas jasa atas penanaman modal (investasi) yang dilakukan investor. Return dapat dibedakan menjadi dua jenis yaitu, return realisasian (realized return) dan return ekspektasian atau (expected return). (Hartono, 2014).

Objek penelitian akan dilakukan pada perusahaan telekomunikasi yang terdaftar pada Bursa Efek Indonesia. Objek ini dipilih karena semakin pesatnya perkembangan teknologi dibidang telekomunikasi membuat segala hal yang berhubungan dengan komunikasi menjadi semakin mudah dan murah. Banyak produsen alat telekomunikasi melakukan berbagai inovasi dan mampu bersaing dipasar global termasuk Indonesia. Fenomena yang akan diteliti mengenai penyebab fluktuasinya return saham baik berasal dari kinerja keuangan perusahaan, manajemen risko maupun manajemen modal kerja terhadap return yang dibagikan oleh perusahaan telekomunikasi kepada investornya.

\section{Perumusan Masalah}

Berdasarkan dari penelitian-penelitian terdahulu dapat disimpulkan bahwa rasio-rasio keuangan (DER,ROI,CR, dan TATO) digunakan untuk mengukur kinerja keuangan perusahaan, interest rate bagian dari market risk yang digunakan untuk mengukur manajemen risiko, dan Cash Conversion Cycle (CCC) digunakan untuk mengukur tingkat manajemen modal kerja memberikan hasil yang bervariasi sehingga menimbulkan pertanyaan untuk diteliti lebih lanjut.

Dalam penelitian ini Debt to Equity Ratio digunakan sebagai variabel yang mempengaruhi return saham, atas dasar adanya research gap antara hasil penelitian (Budialim, 2013) dan (Farkhan dan Ika, 2011) dimana hasil penelitiannya menunjukkan bahwa DER tidak memiliki pengaruh terhadap return saham, 
sedangkan (Thrisye dan Simu, 2013) serta (Salim dan Isnurhadi, 2011) menunjukkan DER mempengaruhi secara signifikan terhadap return saham.

Return On Investment diteliti oleh Sunardi (2010) menyatakan bahwa ROI tidak berpengaruh signifikan terhadap return saham, sementara hasil penelitian dari (Hermi dan Kurniawan, 2011) menunjukkan hasil bahwa Return On Investment tidak memiliki pengaruh terhadap return saham sedangkan (Nuryana 2013) menyatakan ROI berpengaruh positif terhadap return saham.

Thrisye dan Simu (2013) Serta Farkhan dan Ika (2011) menunjukkan bahwa Current Ratio tidak berpengaruh signifikan terhadap return saham. Sedangkan hasil penelitian dari (Budialim, 2013) menyatakan bahwa Current Ratio tidak berpengaruh terhadap return saham.

Adanya research gap dari hasil penelitian yang dilakukan oleh (Nuryana, 2013) yang menyatakan bahwa Total Asset Turn Over memiliki pengaruh positif terhadap return saham, sedangkan hasil penelitian yang dilakukan oleh (Farkhan dan Ika, 2011) serta (Thrisye dan Simu, 2013) menunjukkan hasil bahwa Total Asset Turn Over berpengaruh signifikan terhadap return saham.

Okoli (2012) menyatakan hasil penelitian yang dilakukan bahwa suku bunga memiliki pengaruh negatif yang signifikan terhadap Index Oli dan Gas di Bursa Nigeria, sedangkan (Mulyani, 2014) menyatakan dari penelitiannya bahwa suku bunga berpengaruh negatif terhadap Jakarta Islamic Index.

Nilmawati (2011) menyatakan bahwa secara parsial (Cash conversion cycle (CCC) memiliki pengaruh negatif signifikan terhadap kinerja perusahaan. Sedangkan hasil penelitian (Bolek, 2013) menyatakan bahwa (Cash conversion cycle (CCC) berpengaruh signifikan terhadap return.

\section{Tujuan Penelitian}

Adapun yang menjadi tujuan dalam penelitian ini adalah :

1. Untuk menganalisis pengaruh kinerja keuangan perusahaan yang dihitung menggunakan proksi Debt to Equity Ratio (DER), Return On investment (ROI), Current Ratio (CR), dan Total Assets Turn Over (TATO) terhadap return saham perusahaan telekomunikasi yang listing di BEI tahun 2010-2013.

2. Menganalisis pengaruh manajemen risiko diukur menggunakan interest rate yang merupakan bagian dari risiko pasar terhadap return saham perusahaan telekomunikasi yang listing di BEI tahun 2010-2013.

3. Menganalisis pengaruh dari manajemen modal kerja diukur menggunakan Cash conversion cycle (CCC) terhadap return saham perusahaan telekomunikasi yang listing di BEI tahun 2010-2013.

\section{LANDASAN TEORI} Signaling Theory

Signaling theory menjelaskan bahwa laporan keuangan yang baik merupakan sinyal atau pertanda bahwa perusahaan telah melakukan operasi dengan baik. Sinyal yang baik akan direspon dengan baik oleh berbagai pihak yang berkepentingan (Sunardi, 2010). Signaling theory menekankan pada pentingnya suatu informasi yang diterbitkan oleh perusahaan. Menurut Sharpe, Alexander, dan Bailey (1997) pengumuman informasi akuntansi memberikan sinyal bahwa perusahaan memiliki prospek yang baik di masa yang akan datang (good news) sehingga investor berminat untuk melakukan investasi di bursa efek. Salah satu informasi yang dapat dijadikan acuan oleh investor adalah laporan keuangan.
JURNAL

MANAJEMEN

INDONESIA

Vol. 15 - No. 1

April 2015 


\section{Konsep Return Saham}

JURNAL

MANAJEMEN

INDONESIA

Vol. 15 - No. 1

April 2015
Saham merupakan surat berharga sebagai bukti penyertaan atau kepemilikan modal di suatu perusahaan atau institusi yang memberikan hasil investasi bersifat variabel tergantung dari kemampuan investor yang mengelolanya (IDX). Capital gain atau capital loss merupakan selisih dari harga investasi yang dilakukan sekarang dengan harga periode lalu (Hartono, 2014).

Capital gain atau Capital Loss $=\frac{\mathrm{Pt}-\mathrm{Pt}-1}{\mathrm{Pt}-1}$

Apabila harga investasi sekarang $(\mathrm{Pt})$ lebih tinggi daripada harga periode investasi lalu (Pt-1) berarti terjadi keuntungan modal yang disebut dengan capital gain, apabila kondisi sebaliknya terjadi maka akan terjadi kerugian modal atau capital loss

\section{Kinerja Keuangan}

Menurut Fahmi (2011) kinerja keuangan adalah suatu analisis yang dilakukan untuk melihat sejauh mana suatu perusahaan telah melaksanakan dengan menggunakan aturan-aturan pelaksanaan keuangan secara baik dan benar. Kinerja perusahaan merupakan suatu gambaran tentang kondisi keuangan suatu perusahaan yang dianalisis dengan alat-alat analisis keuangan, sehingga dapat diketahui mengenai baik buruknya keadaan keuangan suatu perusahaan yang mencerminkan prestasi kerja dalam periode tertentu.

\section{Rasio Keuangan}

Rasio keuangan merupakan suatu kegiatan untuk membandingkan angkaangka yang terdapat dalam laporan keuangan yang diterbitkan oleh perusahaan dengan cara membagi angka satu dengan angka yang lain (Kasmir, 2014). Perbandingan dapat dilakukan antara satu komponen dengan komponen lain dalam satu laporan keuangan. Hasil dari rasio keuangan digunakan untuk menilai kinerja manajemen dalam suatu periode.

\section{Rasio Solvabilitas}

Rasio solvabilitas merupakan rasio yang digunakan untuk mengukur sejauh mana perusahaan dibiayai dengan utang. Artinya berapa besar beban utang yang ditanggung perusahaan dibandingkan dengan aktiva yang dimiliki.

$$
D E R=\frac{\text { TotalHutang }(\text { Debt })}{\text { TotalModal(Equity })}
$$

\section{Rasio Rentabilitas}

Rasio rentabilitas merupakan rasio yang digunakan untuk menilai kemampuan perusahaan dalam memperoleh keuntungan. Rasio ini juga memberikan ukuran tingkat efektivitas manajemen suatu perusahaan.

$$
R O I=\frac{\text { EarningAfter } \int \text { erest } \wedge \text { Tax }}{\text { TotalAssets }}
$$




\section{Rasio Likuiditas}

Rasio likuiditas merupakan rasio yang menggambarkan kemampuan suatu perusahaan dalam memenuhi kewajiban atau hutang jangka pendek. Artinya apabila perusahaan ditagih oleh pihak yang meminjami dana atau kreditur, perusahaan akan mampu melunasi hutang tersebut terutama yang sudah jatuh tempo.

$$
C R=\frac{\text { ActivaLancar(CurrentAssets) }}{\text { UtangLancar(CurrentLiabilities) }}
$$

\section{Rasio Aktivitas}

Rasio aktivitas merupakan rasio yang digunakan untuk mengukur efektivitas perusahaan dalam menggunakan aktiva yang dimiliki. Rasio ini digunakan untuk mengukur tingkat efisiensi pemanfaatan sumber daya yang dimiliki perusahaan. Rasio aktivitas juga digunakan untuk menilai kemampuan perusahaan dalam melaksanakan aktivitas sehari-hari.

$$
\text { TATO }=\frac{\text { Penjualan }(\text { Sales })}{\text { TotalAktiva }(\text { Total Assets })}
$$

\section{Manajemen Risiko (Risk Management)}

Ketika melakukan investasi pada suatu portofolio terdapat risiko yang dikenal dengan istilah beta. Menurut Hartono (2009) beta merupakan suatu pengukur volatilitas (volaitility) return suatu sekuritas maupun portofolio terhadap return pasar. Beta mengukur mengenai risiko sistematis dari suatu sekuritas atau portofolio relative terhadap risiko pasar. Volaitilitas merupakan fluktuasi dari return-return sekuritas atau portofolio dalam suatu periode tertentu. Manajemen risko menurut Institute of Risk Management diartikan sebagai perpaduan antara kemungkinan dari suatu peristiwa dengan berbagai konsekuensi yang melekat di dalamnya (Coiller, 2009).

$$
\mathrm{BI} \text { rate tahunan }=\frac{\text { Total BI rate selama } 1 \text { tahun }}{12 \text { bulan }}
$$

\section{Manajemen Modal Kerja (Working Capital Management)}

Manajemen modal kerja merupakan pengelolaan sumber jangka pendek suatu perusahaan untuk melangsungkan aktivitas usaha, pendanaan dan optimalisasi likuiditas perusahaan. Manajemen modal kerja memiliki komponen yang penting seperti efisiensi pemanfaatan aktiva lancar dan kewajiban lancar (Ahmad, 2002).

Modal kerja pada hakikatnya merupakan jumlah yang terus-menerus harus ada dalam menopang usaha perusahaan yang menjembatani antara saat pengeluaran bahan atau jasa, dengan waktu penerimaan penjualan (Ahmad, 2002)

Cash Conversion Cycle $(C C C)=\mathrm{DSO}-\mathrm{DPO}$

Dimana: $\quad$ DSO $=\frac{\text { TotalPiutang }}{\text { Penjualan }} \times 365$ hari

$$
\text { DPO }=\frac{\text { UtangLancar }}{\text { (Penjualan-Labakotor }} \times 365 \text { hari }
$$




\section{Perumusan Hipotesis}

JURNAL

MANAJEMEN

INDONESIA

Vol. 15 - No. 1

April 2015
$H_{1}$ Debt to Equity Ratio diduga memiliki pengaruh terhadap return saham

$\mathrm{H}_{2}$ Return on Investment diduga memiliki pengaruh terhadap return saham.

$\mathrm{H}_{3}$ Current ratio diduga memiliki pengaruh terhadap return saham.

$\mathrm{H}_{4}$ Total Assets Turn Over diduga memiliki pengaruh terhadap return saham.

$\mathrm{H}_{5}$ Interest rate diduga memiliki pengaruh terhadap return saham.

$\mathrm{H}_{6}$ Cash Conversion Cycle (CCC) diduga memiliki pengaruh terhadap return saham.

\section{METODE PENELITIAN}

\section{Jenis Penelitian}

Jenis penelitian yang digunakan dalam penelitian ini adalah studi kasus. Menurut Flyvbjerg (2006) penelitian studi kasus merupakan salah satu metode penelitian dalam ilmu sosial dengan melakukan pemeriksaan longitudinal yang mendalam terhadap suatu keadaan atau kejadian yang disebut sebagai kasus dengan menggunakan cara-cara yang sistematis dalam melakukan pengamatan, pengumpulan data, analisis informasi, dan pelaporan hasilnya.

\section{Variabel Penelitian}

Variabel yang akan digunakan dalam penelitian ini adalah variabel dependen yang berupa return saham. Sedangkan variabel independennya adalah kinerja keuangan. Kinerja keuangan diproksi oleh Debt to Equity Ratio (DER), Return On Investment (ROI), Current Ratio (CR), dan Total Assets Turn Over (TATO). Market Risk diproksikan dengan interest rate dan Manajemen Modal Kerja dengan menggunakan proksi Cash Conversion Cycle (CCC). Sedangkan variabel dependen atau variabel bebas yang digunakan dalam penelitian ini yang dipengaruhi oleh variabel independen adalah return saham.

\section{Populasi}

Populasi adalah gabungan dari seluruh elemen yang berbentuk peristiwa, hal atau orang yang memiliki karakteristik serupa yang menjadi pusat perhatian seorang peneliti karena itu dipandang sebagai sebuah semesta penelitian (Ferdinand, 2011).

Populasi dalam penelitian ini adalah seluruh perusahaan telekomunikasi yang terdaftar di Bursa Efek Indonesia (BEI) selama periode 2010-2013 dengan karakteristik :

1) Menerbitkan laporan keuangan setiap tahun selama periode 2010-2013 dan telah melalui proses audit,

2) Tidak pernah terdelisting dari Bursa Efek Indonesia (BEI) selama periode 20102013,

3) Memiliki data yang lengkap terkait dengan variabel-variabel yang digunakan dalam penelitian. Selain itu ada data yang berasal dari Bank Indonesia berupa Bl rate dari tahun 2010-2013.

4) Merupakan perusahaan telekomunikasi yang menyediakan dan memberikan layanan baik berupa jasa maupun produk yang mendukung terselenggaranya telekomunikasi. 


\begin{tabular}{|c|l|}
\hline No & \multicolumn{1}{|c|}{ Nama Perusahaan } \\
\hline 1 & PT Bakrie Telecom Tbk \\
\hline 2 & PT XL Axiata Tbk \\
\hline 3 & PT SMARTFREN Telecom Tbk \\
\hline 4 & PT Inovisi Infracom Tbk \\
\hline 5 & PT Indosat Tbk \\
\hline 6 & PT Tower Bersama Infrastructure Tbk \\
\hline 7 & PT Telekomunikasi Indonesia Tbk \\
\hline 8 & PT Trikomsel Oke Tbk \\
\hline
\end{tabular}

Tabel 1.

Perusahaan

\section{Sampel}

Jenis sampel yang akan digunakan adalah purpose sampling dikarenakan dengan teknik ini peneliti dapat memilih sasaran tertentu yang mampu memberikan informasi yang dikehendaki berdasarkan kriteria yang telah ditetapkan peneliti (Ferdinand, 2011).

Penelitian ini akan menggunakan 8 perusahaan telekomunikasi dari tahun 2010 sampai tahun 2013 sebagai sampel sehingga diperoleh 32 data. Data yang digunakan dalam laporan keuangan berupa piutang, asset lancar, hutang lancar, total asset, total hutang, pendapatan usaha, total modal, beban bunga, laba sebelum pajak, beban pajak, laba setelah pajak, harga saham saat penutupan (closing).

\section{Metode Analisis Data}

Dalam penelitian ini, pengolahan data dilakukan dengan bantuan program SPSS 19.0 for windows. Data sekunder yang telah dikumpulkan, selanjutnya akan diolah dengan menggunakan analisis deskriptif, uji asumsi klasik, uji koefisien determinasi dan selanjutnya dilakukan pengujian hipotesis yang telah dirumuskan.

\section{Uji Normalitas}

Uji normalitas bertujuan untuk menguji apakah dalam model regresi, variabel dependen dan independen memiliki distribusi normal atau tidak. Ada dua cara untuk mendeteksi apakah residual berdistribusi normal atau tidak yaitu dengan melihat analisis grafik normal probability plot dan uji statistik. Pada prinsipnya normalitas dapat dideteksi dengan melihat penyebaran data (titik) pada sumbu diagonal dari grafik atau dengan melihat histogram dari residualnya. Jika data menyebar jauh dari garis diagonal, maka model regresi dikatakan tidak memenuhi asumsi normalitas (Ghozali, 2011).

\section{Koefisien Determinasi $\left(R^{2}\right)$}

Koefisien determinasi $\left(R^{2}\right)$ pada dasarnya digunakan untuk mengukur kemampuan model menjelaskan variasi yang terdapat dalam variabel dependen. Nilai $\left(R^{2}\right)$ yang kecil memiliki arti bahwa kemampuan variabel-variabel independen dalam menjelaskan variasi variabel dependen sangat terbatas. Nilai Adjusted $\left(R^{2}\right)$ digunakan untuk mengevaluasi model yang terbaik. Nilai dari Adjusted $\left(R^{2}\right)$ dapat naik atau turun apabila satu variabel independen ditambahkan kedalam model. Adjusted $\left(R^{2}\right)$ yang bernilai negatif dianggap bernilai nol (Ghozali, 2011). 


\section{Uji Statistik F}

JURNAL

MANAJEMEN

INDONESIA

Vol. 15 - No. 1

April 2015 statistik $\mathrm{F}$ pada dasarnya menunjukkan apakah semua variabel independen atau bebas yang dimasukkan dalam model mempunyai pengaruh secara bersamasama terhadap variabel dependen atau terikat (Ghozali, 2009).

\section{Uji Secara Parsial (Uji Statistik t)}

Uji t digunakan untuk mengetahui pengaruh variabel independen secara sendiri atau masing-masing terhadap variabel dependen Y (Ghozali, 2011).

\section{Analisis Regresi}

Analisis regresi digunakan untuk mengetahui keakuratan hubungan antara Return (variabel dependen) dengan DER, ROI, CR, TATO, interest Rate dan CCC sebagai variabel yang mempengaruhi (variabel independen) dengan persamaan :

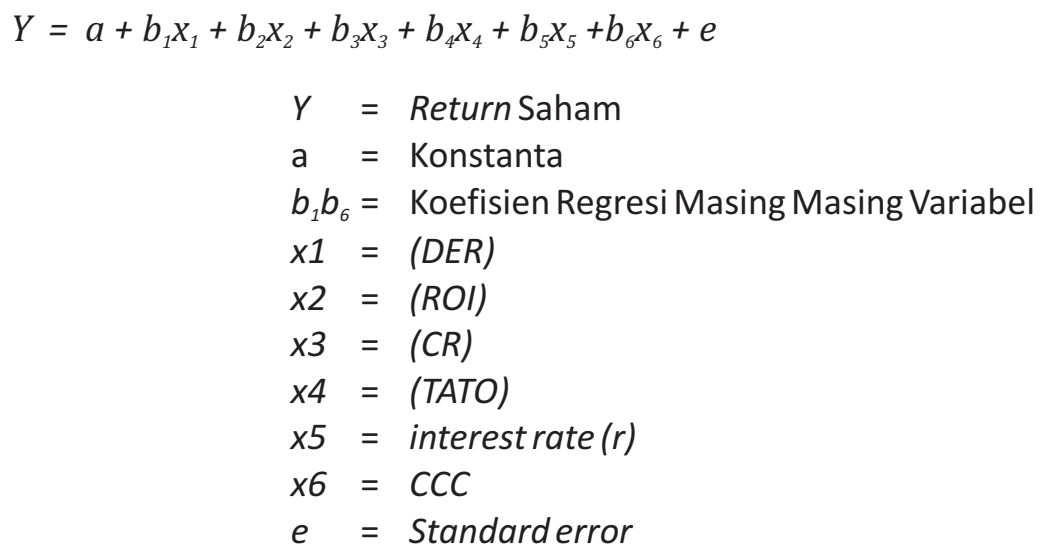

\section{HASIL DAN PEMBAHASAN}

Uji Normalitas

\begin{tabular}{|l|r|}
\hline & \multicolumn{2}{|c|}{$\begin{array}{c}\text { Unstandardized } \\
\text { Residual }\end{array}$} \\
\hline $\mathrm{N}$ & 32 \\
Normal Parameters ${ }^{\mathrm{a}, \mathrm{b}}$ Mean &, 0000000 \\
Most Extreme Differences &, 117 \\
Absolute &, 117 \\
Positive &,- 101 \\
Negative &, 663 \\
Kolmogorov-Smirnov Z &, 772 \\
Asymp. Sig. (2-tailed) & \\
\hline
\end{tabular}

Berdasarkan Tabel 2, menunjukkan bahwa data terdistribusi secara normal. Hal ini ditunjukkan dengan nilai Kolmogorov-Smirnov dengan nilai 0,772 dimana hasil ini menunjukkan tingkat signifikansi diatas $\alpha=5 \%$ atau 0,05 hal ini menunjukkan bahwa data yang ada pada semua variabel yang digunakan terdistribusi secara normal. Hasil ini juga didukung hasil grafik histogram maupun grafik normal probability plot seperti pada Gambar 1 dan Gambar 2 berikut : 


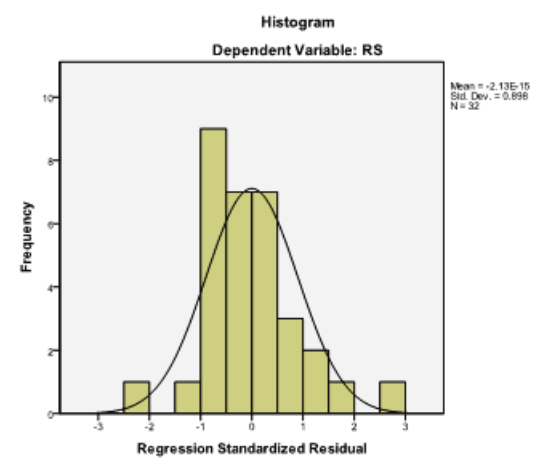

JURNAL

MANAJEMEN

INDONESIA

Vol. 15 - No. 1

April 2015

Gambar 1

Sumber :

Data sekunder

yang diolah 2015

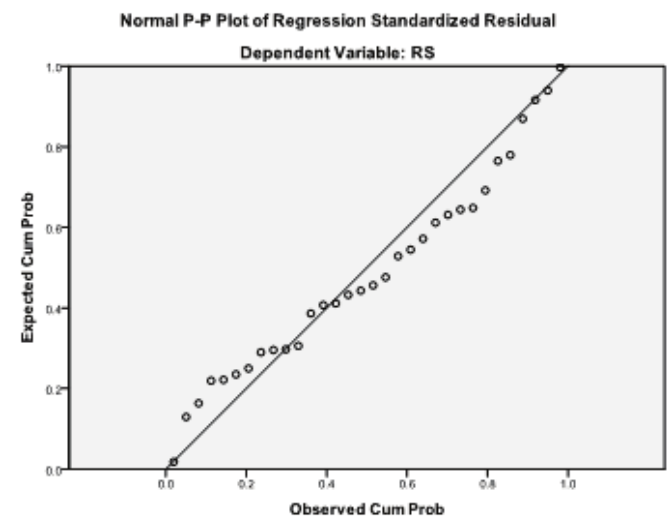

Gambar 2

Sumber :

Data sekunder yang diolah 2015

\section{Koefisien Determinasi}

\begin{tabular}{|l|c|r|lr|}
\hline Model & R & R Square & \multicolumn{2}{|c|}{ Adjusted R Square } \\
\hline 1 & $.730^{\mathrm{a}}$ & .533 & & .421 \\
\hline
\end{tabular}

Dari Tabel 3 diperoleh hasil perhitungan bahwa besarnya pengaruh variabel independen terhadap variabel dependen yang dapat diterangkan oleh model persamaan ini adalah 0.421 atau $42.1 \%$ dan sisanya sebesar $57.9 \%$ diperoleh dari (100\%-42.1\%) dipengaruhi oleh faktor-faktor lain diluar model yang digunakan dalam penelitian seperti Return on Equity (ROE), Earning Per Share (EPS), Dividen Payout Ratio (DPR), dan inflasi.

\section{Uji Kesesuaian Model (Uji Statistik F)}

Uji statisitik F pada dasarnya menunjukkan apakah semua variabel independen atau bebas yang dimasukkan dalam model mempunyai pengaruh secara bersama-sama terhadap variabel dependen atau terikat (Ghozali, 2009).

\begin{tabular}{|c|c|}
\hline F & Sig. \\
\hline 4,760 & ,002 $^{\mathrm{a}}$ \\
\hline
\end{tabular}

Dari hasil analisis regresi dapat diketahui bahwa secara bersama-sama variabel independen memiliki pengaruh terhadap variabel dependen yaitu return saham. Hal ini dapat dibuktikan dari nilai $F$ hitung sebesar 4.760 dengan nilai

Tabel 3.

Koefisien Determinasi Model Summary ${ }^{b}$

Sumber: data sekunder yang diolah, 2015

Tabel 4.

Uji $F$ ANOVA ${ }^{b}$

Sumber: data sekunder yang diolah, 2015 
JURNAL

MANAJEMEN

INDONESIA

Vol. 15 - No. 1

April 2015

Tabel 5.

Hasil Perhitungan Uji t

Sumber:

data sekunder yang diolah, 2015 signifikansi sebesar 0.002 . Karena probabilitas jauh lebih kecil dari $\alpha=5 \%$ atau 0,05 maka model regresi dapat digunakan untuk memprediksi return saham atau dapat dikatakan bahwa Debt to Equity Ratio (DER), Return on Investment (ROI), Current Ratio (CR), Total Asset Turn Over (TATO), interest rate (ir), dan Cash Conversion Cycle (CCC) secara bersama-sama atau simultan memiliki pengaruh terhadap return saham perusahaan telekomunikasi.

\section{Uji Secara Parsial (Uji Statistik t)}

Uji t digunakan untuk mengetahui pengaruh variabel independen secara sendiri atau masing-masing terhadap variabel dependen $Y$. Untuk itu digunakan asumsi :

$\mathrm{HO}: \beta=0$, tidak ada pengaruh variabel independen pada variabel dependen.

Ha: $\beta \neq 0$, tiap variabel independen sebagian atau seluruhnya berpengaruh secara statistik terhadap variabel dependen.

\begin{tabular}{|c|c|c|c|}
\hline Model & $\begin{array}{l}\text { Standardized } \\
\text { Coef.Beta }\end{array}$ & $\mathrm{T}$ & Sig. \\
\hline (Constant) & & $-1,882$ & ,071 \\
\hline DER &,- 403 & $-2,846$ & ,009 \\
\hline ROI &, 450 & 3,029 & ,006 \\
\hline $\mathrm{CR}$ &,- 125 &,- 851 &, 403 \\
\hline TATO &,- 344 & $-2,388$ &, 025 \\
\hline IR & ,311 & 2,087 &, 047 \\
\hline $\mathrm{CCC}$ &, 004 &, 030 & ,977 \\
\hline
\end{tabular}

Hasil pengujian masing-masing variabel independen terhadap variabel dependen terlihat bahwa Debt to Equity Ratio (DER), Return on Investment (ROI) dan Total Asset Turn Over (TATO) memiliki pengaruh terhadap return saham, hal ini dapat dijelaskan bahwa Debt to Equity Ratio (DER), Return on Investment (ROI) dan Total Asset Turn Over (TATO) mempunyai nilai signifikansi lebih kecil dari $\alpha=2,5 \%$ atau 0,025 yaitu masing-masing sebesar 0,009; 0,006; dan 0,025. Sedangkan variabel Current ratio (CR), interest rate (ir), dan Cash Conversion Cycle (CCC) tidak memiliki pengaruh terhadap return saham, yaitu dengan nilai signifikansi 0,403; 0,047; dan 0,977 .

Berdasarkan Tabel 4.4, dapat disusun persamaan regresi linear berganda sebagai berikut:

Return saham $=-0,403 \times 1+0,450 \times 2-0,125 \times 3-0,344 \times 4+0,311 \times 5+0,004 \times 6$

\section{Pembahasan}

\section{Pengaruh Debt to Equity Ratio Terhadap Return Saham}

Dari hasil penelitian diperoleh koefisien regresi sebesar - 0,403 dengan nilai signifikansi sebesar 0,009 . Karena nilai signifikansinya jauh lebih kecil dari $2,5 \%$ atau 0,025 , maka hipotesis pertama dapat diterima yang berarti ada pengaruh antara variabel DER terhadap return saham perusahaan telekomunikasi.

Semakin tinggi nilai rasio DER akan menunjukkan besarnya ketergantungan perusahaan terhadap pihak luar sehingga tingkat risiko yang dihadapi perusahaan semakin besar dalam memenuhi kewajibannya, yaitu membayar pokok hutang ditambah dengan bunga. Hal ini membawa dampak pada menurunnya harga saham yang juga berakibat pada penurunan jumlah return saham yang diterima investor (). 
Artinya semakin tinggi rasio DER suatu perusahaan, dapat mempengaruhi investor dalam mempertimbangkan keputusan investasinya apakah investor tetap berinvestasi dengan risiko yang tinggi dan probabilitas return yang tinggi pula atau sebaliknya.

\section{Pengaruh Return on Investment Terhadap Return Saham}

Dari hasil penelitian diperoleh koefisien regresi sebesar 0,450 dengan nilai signifikansi sebesar 0,006. Karena nilai signifikansinya jauh lebih kecil dari 2,5\% atau 0,025 , maka hipotesis kedua dapat diterima yang berarti ada pengaruh antara variabel ROI terhadap return saham perusahaan telekomunikasi.

Hasil ini menggambarkan bahwa kenaikan Return on Investmen akan berakibat pada meningkatnya pengembalian (return) saham yang diterima investor. Hasil dari penelitian ini sesuai dengan teori yang menyatakan bahwa, ROI yang meningkat akan berdampak pada peningkatan return saham. Perusahaan dengan ROl yang besar akan menarik minat dari investor untuk menambahkan dananya atau investasi ke dalam perusahaan tersebut. Hal ini disebabkan karena ROI yang besar menunjukkan kinerja perusahaan semakin baik dan berdampak pada peningkatan return saham yang diterima investor (Thrisye \& Simu, 2013).

\section{Pengaruh Current Ratio Terhadap Return Saham}

Dari hasil penelitian diperoleh koefisien regresi sebesar $-0,125$ dengan nilai signifikansi sebesar 0,403. Karena nilai signifikansinya jauh lebih besar dari 2,5\% atau 0,025 , maka hipotesis ketiga tidak dapat diterima yang berarti CR tidak berpengaruh terhadap return saham perusahaan telekomunikasi.

Kenaikan Current Ratio akan berakibat pada menurunnya tingkat pengembalian (return) saham yang diterima investor. Temuan ini sesuai dengan teori yang menyatakan bahwa Current Ratio tinggi menunjukkan tingkat likuiditas yang tinggi dan mengindikasikan kinerja perusahaan yang kurang mampu dalam mengelola keuangan, selain itu current ratio yang tinggi belum tentu menjamin akan dibayarnya hutang perusahaan yang sudah jatuh tempo karena proporsi dari aktiva lancar yang tidak menguntungkan apabila terdapat saldo kas yang berlebihan. Sedangkan current ratio yang rendah menunjukkan bahwa terjadi suatu masalah yang berkaitan dengan likuiditas yang juga dapat diartikan sebagai indikasi ketidak mampuan perusahaan dalam memenuhi kewajiban jangka pendek (Thrisye dan Simu, 2013).

\section{Pengaruh Total Asset Turn Over Terhadap Return Saham}

Dari hasil penelitian diperoleh koefisien regresi sebesar -0,344 dengan nilai signifikansi sebesar 0,025. Karena nilai signifikansinya sama dengan $2,5 \%$ atau 0,025 , maka hipotesis keempat dapat diterima yang berarti ada pengaruh antara variabel TATO terhadap return saham perusahaan telekomunikasi.

Nilai Total Asset Turn Over yang tinggi mengindikasikan bahwa perusahaan dapat melakukan penjualan dari setiap aktiva yang dimiliki secara optimal yang berarti perusahaan dapat mendayagunakan seluruh aktiva yang dimiliki (Risca Yuliana Thrisye, 2013). Total Asset Turn Over pada perusahaan telekomunikasi memberikan gambaran bagaimana aktiva yang dimiliki oleh perusahaan dioptimalisasikan untuk menghasilkan pendapatan atas aktivitas yang dilakukannya. Namun optimalisasi perusahaan menggunakan aktiva untuk menghasilkan pendapatan belum dijadikan sinyal positif bagi investor dalam memprediksi return saham berupa capital gain.
JURNAL

MANAJEMEN

INDONESIA

Vol. 15 - No. 1

April 2015 


\section{Pengaruh interest rate Terhadap Return Saham}

JURNAL

MANAJEMEN

INDONESIA

Vol. 15 - No. 1

April 2015
Dari hasil penelitian diperoleh koefisien regresi sebesar 0,311 dengan nilai signifikansi sebesar 0,047 . Karena nilai signifikansinya jauh lebih besar dari 2,5\% atau 0,025 maka hipotesis kelima tidak dapat diterima yang berarti interest rate tidak berpengaruh terhadap return saham perusahaan telekomunikasi.

Hasil ini menggambarkan bahwa kenaikan interest rate tidak akan berakibat pada meningkatnya tingkat pengembalian (return) saham yang diterima investor. Di samping itu, tingkat suku bunga atau BI rate yang meningkat tidak membuat investor yang memiliki saham di perusahaan telekomunikasi khawatir. Hal ini dikarenakan perusahaan telekomunikasi merupakan perusahaan jasa atau perusahaan yang bergerak dalam sektor non riil (Bank Indonesia, 2014). Sedangkan untuk perusahaan yang tergolong dalam sektor riil akan terpengaruh oleh perubahan tingkat suku bunga yang dikeluarkan oleh $\mathrm{Bl}$.

Jadi hubungan antara tingkat bunga atau interest rate terhadap return saham berbanding terbalik untuk perusahaan yang tergolong dalam sektor riil , dimana jika tingkat suku bunga naik maka return saham akan turun dan sebaliknya. Untuk sektor non rill hubungan antara tingkat suku bunga dengan return saham berbanding lurus. Namun apabila investor membeli saham pada saat tingkat suku bunga tinggi maka mereka akan mengeluarkan uang yang sedikit untuk berinvestasi, dan menjaga investasinya hingga suku bunga stabil sehingga investor akan mendapatkan return saham yang menjanjikan.

\section{Pengaruh Cash Conversion Cycle Terhadap Return Saham}

Dari hasil penelitian diperoleh koefisien regresi sebesar 0,004 dengan nilai signifikansi sebesar 0,977. Karena nilai signifikansinya jauh lebih besar dari 2,5\% atau 0,025, maka hipotesis keenam tidak dapat diterima yang berarti CCC tidak berpengaruh terhadap return saham perusahaan telekomunikasi.

Tidak adanya pengaruh antara Cash Conversion Cycle dengan return saham perusahaan telekomunikasi dikarenakan investor tidak mengambil keputusan investasi mereka dengan melihat nilai CCC, dikarenakan nilai ini tidak dicantumkan dalam laporan keuangan sehingga investor harus menghitung sendiri nilai rasio ini.

Menurut (Wilujeng, 2009) dalam (Nilmawati, 2011) Perusahaan yang dapat memperpendek waktu CCC dapat mempercepat penjualan yang ada, mempercepat periode penagihan piutang dan memperlambat pembayaran kewajiban. Perusahaan yang memiliki waktu CCC yang pendek mampu mengumpulkan cash yang diperlukan untuk operasional sehari-hari perusahaan, sehingga tidak perlu menggunakan sumber dana dari luar yang berarti tidak ada biaya untuk pinjaman dana, hal ini akan meningkatkan laba perusahaan yang juga akan meningkatkan return saham yang diterima investor.

\section{KESIMPULAN}

1. Debt to Equity Ratio (DER) berpengaruh terhadap return saham perusahaan telekomunikasi. Karena DER berbanding terbalik dengan return saham maka dapat disimpulkan apabila tingkat DER suatu perusahaan semakin tinggi dapat dipastikan bahwa risiko yang ditanggung oleh perusahaan juga semakin tinggi, dimana profit yang diperoleh perusahaan semakin berkurang akibat dari pembayaran kewajiban ditambah dengan bunga kepada pihak ketiga, hal ini juga akan membuat tingkat return saham yang diperoleh investor juga berkurang. 
2. Return on Investmen (ROI) berpengaruh terhadap return saham perusahaan telekomunikasi . Hasil penelitian yang signifikan antara ROI dan return saham disebabkan oleh hubungan yang positif antara tingkat rasio ROI dengan return saham, dimana ROI merupakan rasio yang menunjukkan mengenai kemampuan perusahaan dalam menghasilkan profitabilitas.

3. Current Ratio (CR) tidak memiliki pengaruh terhadap return saham perusahaan telekomunikasi. Tidak adanya pengaruh antara Current Ratio dan return saham dikarenakan CR merupakan indikasi yang menunjukkan mengenai kemampuan perusahaan dalam memenuhi kewajiban jangka pendeknya. Dimana rasio CR yang tinggi menunjukkan tingkat likuiditas yang tinggi.

4. Total Asset Turn Over (TATO) memiliki pengaruh terhadap return saham perusahaan telekomunikasi. Total Asset Turn Over pada perusahaan telekomunikasi memberikan gambaran bagaimana aktiva yang dimiliki oleh perusahaan dioptimalisasikan untuk menghasilkan pendapatan atas aktivitas yang dilakukannya.

5. interest rate (ir) tidak memiliki pengaruh terhadap return saham perusahaan telekomunikasi. Tidak adanya pengaruh antara ir dan return saham dikarenakan tingkat bunga yang tinggi merupakan sinyal positif bagi investor untuk membeli sejumlah saham yang dikeluarkan emiten. Di samping itu, tingkat suku bunga atau $\mathrm{BI}$ rate yang meningkat tidak membuat investor yang memiliki saham di perusahaan telekomunikasi khawatir. Hal ini dikarenakan perusahaan telekomunikasi merupakan perusahaan jasa atau perusahaan yang bergerak dalam sektor non riil yang tidak terkena mekanisme perubahan BI rate.

6. Cash Conversion Cycle (CCC) tidak memiliki pengaruh terhadap return saham perusahaan telekomunikasi. Tidak adanya pengaruh positif antara CCC dan return saham dikarenakan investor tidak mengambil keputusan investasi mereka dengan melihat nilai CCC, dikarenakan nilai ini tidak dicantumkan dalam laporan keuangan sehingga investor harus menghitung sendiri nilai rasio ini.

\section{SARAN}

Dari nilai koefisien regresi Debt to Equity Ratio atau DER yang negatif menunjukkan bahwa total modal yang dibandingkan dengan total hutang yang dimiliki perusahaan telekomunikasi jumlahnya lebih besar. Sebaiknya manajer dapat mendayagunakan modal yang dimiliki perusahaan untuk memenuhi kebutuhan operasional dan mengambil keputusan pendanaan berupa hutang dari pihak ketiga untuk melakukan ekspansi usahanya, akan tetapi jumlahnya harus disesuaikan dengan kebutuhan dan kemampuan perusahaan dalam memenuhi kewajibannya.

Nilai koefisien regresi Return on Investment atau ROI yang positif menunjukkan bahwa laba bersih setelah bunga dan pajak atau EAT yang dibandingkan dengan total aktiva yang dimiliki perusahaan telekomunikasi jumlahnya lebih besar. Sebaiknya manajer dapat terus menjaga kinerjanya agar profitabilitas yang diperoleh perusahaan terus meningkat dan membawa kesejahteraan baik untuk perusahaan, karyawan maupun investornya.

Nilai koefisien regresi Current Ratio atau CR yang negatif menunjukkan bahwa aktiva lancar (current assets) dibandingkan dengan hutang lancar (current liabilities) yang dimiliki perusahaan telekomunikasi jumlahnya lebih kecil sehingga hasil rasionya negatif. Sebaiknya manajer dapat lebih cepat dalam melunasi kewajiban jangka pendek yang dimiliki perusahaan agar perusahaan berada pada kondisi likuid.
JURNAL

MANAJEMEN

INDONESIA

Vol. 15 - No. 1

April 2015 
JURNAL

MANAJEMEN

INDONESIA

Vol. 15 - No. 1

April 2015
Nilai koefisien regresi Total Asset Turn Over atau TATO yang negatif menunjukkan bahwa penjualan atau sales yang dibandingkan dengan total aktiva yang dimiliki perusahaan telekomunikasi jumlahnya lebih kecil. Diharapkan perusahaan dapat meningkatkan penjualan dengan melakukan bauran pemasaran untuk menarik minat konsumen yang akan berakibat pada peningkatan laba yang diperoleh.

Nilai koefisien regresi interest rate atau ir yang positif menunjukkan bahwa kondisi perekonomian di Indonesia kurang baik. Manajer diharapkan dapat mengambil keputusan investasi yang tepat dalam kondisi seperti ini, seperti keputusan untuk menambah pendanaan dengan menjual saham kepada investor. Dimana dalam kondisi ini harga saham akan anjlok dan dana yang diperoleh dari penjulan saham kurang mencukupi dalam memenuhi permodalan yang dibutuhkan.

Nilai koefisien regresi Cash Conversion Cycle atau CCC yang positif menunjukkan perputaran hari penjualan atau DSO yang dibandingkan dengan perputaran hari hutang yang dimiliki perusahaan telekomunikasi jumlahnya lebih besar. Sebaiknya manajer dapat menerapkan berbagai strategi dalam mempercepat perputaran CCC seperti mempercepat penagihan piutang dan memperlambat pembayaran kewajiban.

\section{KETERBATASAN PENELITIAN}

Penelitian ini mempunyai keterbatasan, terutama dalam hal:

Hasil penelitian menunjukkan kecilnya pengaruh Debt to Equity Ratio, Return on Investment, Current Ratio, Total Asset Turn Over, interest rate, dan Cash Conversion Cycle terhadap variabel dependen yaitu Return saham yang dapat diterangkan oleh model regresi pada perusahaan telekomunikasi hanya sebesar $42,1 \%$ dan sisanya sebesar 57,9 \% dipengaruhi oleh faktor-faktor lain yang tidak dimasukkan dalam penelitian.

Penelitian ini juga terbatas pada perusahaan dengan pengamatan yang relatif pendek yaitu selama empat tahun dengan sampel yang terbatas yaitu 8 perusahaan. Disamping itu dalam penelitian ini ada yang berbeda dengan hipotesis yang diajukan mengindikasikan masih sempitnya lapangan penelitian sehingga kurang dapat memberikan gambaran yang masih komprehensif mengenai pengaruh Debt to Equity Ratio, Return on Investment, Current Ratio, Total Asset Turn Over, interest rate, dan Cash Conversion Cycle, sehingga perlu dikembangkan dengan menambahkan faktor-faktor lain seperti Return on Equity (ROE), Earning Per Share (EPS), Dividen Payout Ratio (DPR), dan inflasi.

\section{DAFTAR PUSTAKA}

Ahmad, Kamaruddin. (2002). Dasar-Dasar Manajemen Modal Kerja, Jakarta: PT Rineka Cipta.

Bank Indonesia, (2014). Transmisi Kebijakan Moneter. Available at: www.BI.go.id

Bolek, Monika. (2013). Working Capital Management, Profitability And Risk - Analyse of Companies Listed on The Warsaw Stock Exchange. eFinanse 9: 10.

BPS. (2014). Persentase Pengeluaran Rata-rata per Kapita Sebulan Menurut Kelompok Barang, Indonesia 1999-2013. Available at: www.bps.go.id.

Budialim, Giovani. (2013). Pengaruh Kinerja Keuangan dan Risiko Terhadap Return Saham Perusahaan Sector Consumer Goods di BEI (2007-2011). Calyptra : Jurnal Ilmiah Mahasiswa Universitas Surabaya 2: 1-23.

Coiller, Paul M. (2009). Fundamental of Risk Management for Accountants and Managers. Burlington, MA 01803, USA: Butterworth-Heinemann. 
Fahmi, Irham. (2011). Analisis Kinerja Keuangan. Bandung: Alfabeta.

Farkhan dan Ika. (2011). Pengaruh Rasio Keuangan terhadap return saham perusahaan manufaktur di BEl. Value Added 9: 1-18.

Ferdinand, Augusty. (2011). Metode Penelitian Manajemen, Semarang: Badan Penerbit Universitas Diponegoro.

Flyvbjerg, Bent. (2006). Misunderstandings About Case Study Research "Qualititative Inquiry". Available at: http://id.wikipedia.org/wiki/Studi_kasus.

Ghozali, Imam. (2009). Aplikasi Analisis Multivariate dengan Program SPSS, Semarang: Badan Penerbit Universitas Diponegoro.

Ghozali, Imam. (2011) Aplikasi Analisis Multivariate dengan Program IBM SPSS 19, Semarang: Badan Penerbit Universitas Diponegoro.

Hartono, Jogiyanto. (2014). Teori dan Praktik Portofolio dengan Excel, Jakarta: Salemba Empat.

Hermi dan Kurniawan, Ary. (2011). Pengaruh Kinerja Keuangan Terhadap Return Saham Pada Perusahaan Manufaktur yang terdaftar di BEI 2008-2010. Jurnal Informasi, Perpajakan, Akuntansi dan Keuangan Publik 6: 83-95.

Husnan, S. (1994). Dasar Teori Portofolio dan Analisis Sekuritas, Edisi 2, UPP AMP- YKPN, Yogyakarta.

IDX, Indonesian Stock Exchange. Sekolah Pasar Modal BEI Level 1. In: Indonesia, Bursa Efek (ed). Indonesia: IDX.

Kasmir. (2014). Analisis Laporan Keuangan, Jakarta: Rajawali Pers.

Mulyani, Neny. (2014). Analisis Pengaruh Inflasi, Suku Bunga, Nilai Tukar Rupiah dan Produk Domestik Bruto Terhadap JII. Jurnal Bisnis dan Manajemen Eksekutif 1:13.

Nilmawati. (2011). Pengaruh Manajemen Modal Kerja pada Kinerja Perusahaan yang Terdaftar di Bursa Efek Indonesia. Karisma 5: 12.

Nuryana, Ida. (2013). Pengaruh Rasio Keuangan Terhadap Return Saham Perusahaan LQ45 di BEJ. Jurnal Akuntansi Aktual 2: 57-66.

Okoli, Margaret Nnenna. (2012). Verifying the Effects of Risk Variables on Return Volatility of Sector Price Indices in the Nigeria Stock Exchange. Asian Economic and Financial Review 2: 7.

Thrisye, Risca Yuliana dan Simu, Nicodemus. (2013). Analisis Pengaruh Rasio Keuangan Terhadap Return Saham BUMN Sektor Pertambangan Periode 2007-2010. Jurnal IImiah Akuntansi dan Bisnis 8: 1-7.

Salim, Elly dan Isnurhadi. (2011). Pengaruh Kinerja Keuangan Perusahaan Terhadap Return Saham Pada Perusahaan Sektor Makanan dan Minuman Di BEI. Jurnal Manajemen Bisnis Surabaya 9: 71-86.

Sunardi, Harjono. (2010). Pengaruh Penilaian Kinerja dengan ROI dan EVA terhadap Return Saham Perusahaan yang tergabung dalam indeks LQ45 di BEI. Jurnal Akuntansi 2: 7092.

Sharpe, William F., Alexander, Gordon J., dan Bailey, Jeffrey V. (1997). Investments. In: 2nd (ed). Upper Saddle River, New Jersey: Prentice Hall, Inc, 211.

Wilujeng, Syarif (2009). Cash Conversion Cycle dan Hubungannya dengan Ukuran Perusahaan, Profitabilitas dan Manajemen Modal Kerja. Jurnal Ekonomi Bisnis: 9. 
JURNAL

MANAJEMEN

INDONESIA

Vol. 15 - No. 1

April 2015

Jurnal Manajemen Indonesia 